\title{
Bullying, Prejudice and Barbarism*
}

\author{
Denise Raissa Lobato Chaves, Mauricio Rodrigues de Souza \\ Institute of Philosophy and Human Sciences, Federal University of Pará, Belém, Brazil \\ Email: denny.raissa@gmail.com, souza.mr@gmail.com
}

Received 22 March 2016; accepted 14 June 2016; published 17 June 2016

Copyright (C) 2016 by authors and Scientific Research Publishing Inc.

This work is licensed under the Creative Commons Attribution International License (CC BY).

http://creativecommons.org/licenses/by/4.0/

(c) (i) Open Access

\begin{abstract}
Among the many kinds of violence at school, bullying is one of the most important subjects. This phenomenon consists of intentional physical and psychological violence directed to a specific person, who is considered fragile and inferior by the bully. Thus, bullying provides short and long term negative consequences to all involved, and is presents as potentially related to denial and rejection of others. Therefore, this research analyzes the conceptual limitations of bullying by utilizing Critical Theory as its main theoretical framework-more specifically the ideas of Theodor Adorno and Max Horkheimer about education, emancipation, and prejudice. Lastly, it denounces the naturalization of bullying at school, and the alienation to the concept, revealing it to be a new form of barbarism that remains today.
\end{abstract}

\section{Keywords}

Bullying, Prejudice, Barbarism, Critical Theory

\section{Introduction}

School is an institution that is usually considered to have as its primary function the diffusion of relevant knowledge concerning civility and personal growth, besides preparing individuals for the job market. For this reason, violence in school environment has become a matter of concern, interest and studies as it is considered a serious and complex social problem.

In this context, bullying gained notoriety during the end of the last decade as a partially veiled phenomenon, often being disregarded by education professionals (Lopes-Neto, 2005; Antunes, 2008). In general terms, it deals with the intentional use of physical and psychological violence against specific individuals, but its prevalence in school context should be further investigated (Olweus, 1993).

As it is erroneously thought of as part of a child's development and as something that has always existed in

\footnotetext{
*This paper resulted from a research funded by the Institutional Scholarship Program for Scientific Initiation of Federal University of Pará (2013/2014). Also, it had financial support from PROPESP-UFPA and FADESP.
} 
schools around the world, however, this phenomenon is at risk of becoming naturalized (Fante, 2005; Pereira, 2008). In light of that, this article intends to understand and analyze bullying through a critical perspective that advances the investigation of the phenomenon rather than merely describing it conceptually.

Therefore, in here we present a comparative analysis of the literature on bullying, an analysis that has Critical Theory of Society as its theoretical framework. We believe that this will allow us to question this concept as it presents, at the same time, a historical and reflective aspect. It takes into account that no knowledge is neutral, and that investigation of a specific object can also bear social, political and economical interests originated or associated with it. Furthermore, we expose bullying's process of naturalization in school environment and the concept's alienation, presenting the close relation between this phenomenon and prejudice, bringing light to its proximity to new forms of barbarism that continue to exist today.

\section{The Bullying Phenomenon}

The notion of bullying refers to the combination of violent actions against an individual. These actions are repeatedly taken by one or more subjects (Olweus, 1997, 2013). It can take place in various contexts, such as work environments, prisons, apartment blocks and other spaces that are impregnated with interpersonal relationships. Despite that, the occurrence of bullying in school environments is the most studied and emphasized phenomenon (Fante, 2005).

Bullying is seen as a subcategory of aggressive behavior, which is defined as an intentional behavior with the objective of inflicting damage, or causing discomfort to someone (Solberg et al., 2007; Bandeira, 2009). To characterize bullying and set it apart from other aggressive behaviors, Olweus $(1993,1997,2013)$ states that there must be an imbalance in the power relationship caused by age difference, stature, physical strength, emotional development and support from their peers. Due to these factors, the victims would not be able to defend themselves or react assertively against the aggression (Olweus, 1997).

The term bullyinghas its origins in the English language and its meaning can be related to "intimidate" and "to act with cruelty". According to Antunes (2008), different countries already had a variety of terms originally used to refer to behaviors that could easily fit into the concept of bullying. It is precisely because of that variety that the English expression has been chosen and elevated to concept of scientific nature aiming to facilitate the classification, identification, and intervention to what concerns the phenomenon. Aggressive acts such as: kicking, pushing, giving nicknames, calling names, unjustly accusations, ridicule, intentionally excluding, threatening and slandering are all examples of violent practices in bullying, which occur in the absence of any adult or responsible person (Fante, 2005; Antunes \& Zuin, 2007; Antunes, 2008; Ristum, 2010).

In his research, Olweus (1993) presents that some students refer to external characteristics of their victims (for example, obesity, the use of corrective glasses, red hair, etc.) as causes that would explain bullying them. However, the author affirms that, although these external characteristics could be associated with this phenomenon, they did not have the major role in its origin and, as such, should not be too conceptually emphasized. According to this, Limber and Olweus (2010) argue that bullying can be considered a form of abuse as it occurs even without apparent provocation from the individual suffering these aggressions. And, to identify and differentiate it from other forms of abuse and domestic violence, the context in which it occurs and the relationships between the parties must be considered.

In conclusion, bullying is generally characterized by three factors: 1 ) aggressive behavior with the intent of provoking damage; 2) repeatedly occurrence of this behavior; 3) occurrence of aggressive behavior in interpersonal relationships that present power imbalance (Olweus, 1993, 1997). In addition, bullying can also be classified as direct or indirect. Indirect bullying is linked to non-explicit and almost imperceptible actions-for example, to intentionally exclude or spread rumors. This opposes the former, which is characterized as a combination of explicit actions, such as physical and verbal aggression (Olweus, 1997, 2013; Fante, 2005; Bandeira, 2009).

In addition to the general concept, Olweus (2003) and Limber and Olweus (2010) acknowledge that bullying presents a specific dynamic called Bullying Circle, which is composed of roles characterized by actions and behaviors manifested by the involved parties: the aggressor/bully and the victim/deal. According to this dynamic, the victim/deal can be passive or provocative. The passive victim is characterized as lonely, shy and quiet. While suffering aggression they feel incapable of asking for help or defending themselves and usually do not respond to the aggression in any violent way. In situations of aggression, the victim tends to lower their self-esteem and have a negative view of the situation. The provocative victim presents anxiety and aggressive behavior, 
eliciting aggressive reactions from their peers. Furthermore, in the bullying dynamic only the victim is exposed as a target of the aggression initiated by the aggressor/bully (Olweus, 1997, 2003; Fante, 2005).

The aggressor/bully is characterized as the subject that has initiated the bullying and has active participation in its occurrence. The subject that assumes this role is described as someone who imposes authority through aggressive action combined with physical or psychological strength. The aggressor/bully demonstrates a need for power and domination and this need is generally associated with insecurity and anxiety (Olweus, 1997, 2003). In addition, authors like Fante (2005) and Antunes (2008) propose that the aggressor/bully does not necessarily present cause or apparent reason for manifesting aggressive behaviors and, as they are singled out in front of other classmates, they can also be seen as a role model by others.

According to Fante (2005), Lopes-Neto (2005) and Limber and Olweus (2010), however, the bullying dynamic is complemented by roles other than those of the victim/deal and aggressor/bully described above. There would also be those who witness bullying, participants and actively involved parties other than the main aggressor/bully, those who take the initiative of helping the victim suffering the aggression and also those who witness the aggression and try to back away in fear of being next.

Because of the physical and psychological violence, bullying usually brings along short and long term effects to all participants. In short term, one could consider that the victim will present insomnia, psychosomatic reactions, depreciating thoughts and difficulty in interacting with other classmates. In the long term, the victim can present difficulty in having relationships with other people and the actions that they experience can influence the development of states of depression, possibly leading to suicide. In relation to the aggressor, in short terms there can be consolidation of his or her authoritarian conduct, which implies consequences further ahead. For example, difficulty in relationships due to a history of aggressive behavior. Throughout their lives the aggressors can be prone to committing infractions. As to the other parties involved, it is possible that they will develop interpersonal relationship problems in the future, even though they had not taken active part in the aggressions (Fante, 2005; Pereira, 2008).

This major concern in defining and specifying the concept of bullying can, on the other hand, underscore the distancing from reality and from social, historical, economical and cultural issues through abstraction. Thus, as exposed before, the present article seeks to question the conceptual literature on bullying and its limitations by using ideas proposed by Critical Theory, ideas that will be briefly commented upon in the following segment.

\section{Brief Comments on Critical Theory}

Critical Theory (or Critical Theory of Society) refers to an intellectual movement originally developed by members of the Institute for Social Research (Institutfür Sozialforschung) of the Frankfurt University, in Germany, during the 1930's. In its development, Critical Theory received direct influence from the Marxist ideology. However, it has been characterized throughout time as a multidisciplinary body that has evolved from sociology and economy to psychoanalysis.

Critical Theory was first referenced in Max Horkheimer's essay entitled Traditional and Critical Theory, in which the author presented his proposition for a social multidisciplinary theory, opposing what he called traditional theory. To Horkheimer (1937/1976), the knowledge that was produced through traditional theory was valued for its practical application, serving to the interests of capital, preserving class society and presenting inhuman aspects in its composition such as wars and oppression.

In this perspective, Horkheimer (1937/1976) considers that in the model proposed by traditional theory there was a predominance of irrationality, as scientific knowledge distances itself from political issues, with no perspective of promoting changes in the current social status-which would culminate in barbarism. As of this, Critical Theory differs from traditional theory concerning the researcher's stance before society, since it takes into account the influence of historical and social aspects in scientific production and presents as its objective the emancipation of this society's current model in order to prevent barbarism.

The term "critical”, present in Critical Theory, is associated with Critique of Pure Reason, by Kant (1781/ 1990), in which reason is placed as the subject of the critique of knowledge. In such context, self-criticism is shown as a fundamental component at adulthood's reach, a state in which man would leave his condition of pupil and would become responsible for his actions.

In historical terms, Critical Theory presents a trajectory composed of three moments. At the beginning of the 1930's, its first phase had Max Horkheimer's initial proposition as its goal, which consisted of, by direct influ- 
ence of Marxism, creating a transdisciplinary social philosophy. At the beginning of the 1940's, a second phase presented Theodor Adorno and Max Horkheimer as exponents of a movement that focused in emancipation and stood against barbarism, including Freudian psychoanalysis in its theoretical framework. Finally, Critical Theory's third phase is characterized, among other things, by the adoption of communication theory of society, a contribution by Habermas (Tar, 1977; Slater, 1977; Matos, 1993; Honneth, 1988; Jay, 1996; Rush, 2004).

\section{Theodor Adorno: Enlightenment, Prejudice and Education for Emancipation}

Following what has already been stated, Theodor Adorno's influence on Critical Theory was manifested in the 1940's. For instance, when he developed, along with Max Horkheimer, the essays that formed Dialectic of Enlightenment ${ }^{1}$. Adorno's works on education and barbarism throughout his theoretical production deserve great praise. Adorno considers education to be a means of production for true consciousness and has as its main objective the prevention of barbarism. The latter, however, is thought of as a result of the civility process and is constituted by subjective mechanisms related to self-destructive impulses.

Considering these aspects, in texts such as Education After Auschwitz Adorno (1971a) proposes ideas for an education towards critical self-reflection and emancipation, focusing on early childhood and, later on, turning to the general enlightenment of the population. Adorno (1971b) considers that education changed following the historical process of humanity, being also considered a dialectic element formed by the duality between adaptation and autonomy. According to him, an education process predominantly adaptive would result in mere transmitting of knowledge and collaborates to an attitude of acceptance and adjustment to any knowledge acquired. It is before such a threat that Adorno (1971c) defends a debarbarization of adaptive education, electing self-reflection as a fundamental element in the educational process, seeking to achieve an autonomous education towards transformation.

Returning to Dialectic of Enlightenment, there are two essays in particular worth highlighting, which we believe to provide some important elements for reflection on bullying. The first one, named The Concept of Enlightenment, seeks to understand how rationality-more precisely, the instrumental rationality supported by the concept-was established during the development of the western civilization. Moreover, Horkheimer and Adorno (1947/2002a) discuss man's dominance over nature and the alleged justification for that: fear of the unknown. As such, following the history of mankind, enlightenment (Aufklärung) had come to rid men of this fear and, consequently, of the myths that were created because of it. From the perspective of enlightenment, mythology's fundamental element resided in the projection of the subjective on nature and, because of that, man had allowed himself to be frightened by it. So, in order to overcome myth, enlightenment was used to dominate the unknown and to be capable of replacing imagination with knowledge.

However, Horkheimer and Adorno (1947/2002a) suggest that both instances (myth and enlightenment) are entwined and not heterogeneous, since mythology already had as its objectives the explanation and fixation of knowledge, goals usually associated with enlightenment. On the other hand, enlightenment itself also assumes mythical aspects as it is composed by abstract magnitude and concepts.

Therefore, abstraction as an instrument of enlightenment transforms nature into reproducible concepts, separating subject from object and adding a dominating relation. That is, when domination is established through the concept, comprehension and dominion over reality is to be assumed. Thus, Horkheimer and Adorno (1947/ 2002a) argue that enlightenment is dialectical for presenting both emancipatory dimension focused on the organization of civilization and an instrumental part of this process, a part that results in the alienation of man in relation to the elements created by him, as well as an unreflecting attitude towards them.

For Horkheimer and Adorno (1947/2002a), this process of rationalizing the world through enlightenment also results in impoverishing man's relation with nature. That is, these relations have been reduced to domination and manipulation, emphasizing here the loss of reason, reflection and autonomy's emancipatory potential. Following this, the authors complement their arguments by considering that: “(...) the relationships of human beings, including the relationship of individuals to themselves, have themselves been bewitched by the objectification of

\footnotetext{
${ }^{1}$ Collection of essays that discuss themes such as: the ambiguity of enlightenment (Aufklärung), cultural industry, anti-Semitism and other important elements to Critical Theory. Here we see that Theodor Adorno and Max Horkheimer present as their main focus of debate the civilizatory process and its progress linked to the idea of barbarism. Furthermore, the essays sought to understand why human rationality, instead of emancipating and establishing a free and equal men society, creates the opposite. To Horkheimer, this work aimed to provide philosophical basis for Critical Theory, but to Adorno it also meant a possibility to discuss barbarism and civilization, as well as establishing criticism to the idea of progress (Wiggershaus, 1994; Duarte, 2002; Rabaça, 2004; Nobre, 2008).
} 
mind” (p. 21). In this perspective, intolerant practices such as anti-Semitism can be presented as consequences of the totalitarian dimension of enlightenment.

Here we find the theme of Dialectic of Enlightenment's second essay, which is particularly interesting to us, named Elements of anti-Semitism: limits of Enlightenment ${ }^{2}$. In it, Horkheimer and Adorno (1947/2002b) present an analysis of prejudice in which they discuss, among other things, the function of Jews in western civilization, evidencing some objective and subjective circumstances that have made anti-Semitism possible. The essay itself is divided into seven theses. The first four examine socioeconomic and religious motivations for anti-Semitism, while the other three refer to subjective factors, such as mimetic behavior, false projection and the ticket mentality. Let us look at these last three ${ }^{3}$.

Therefore, on the fifth thesis of Elements, Horkheimer and Adorno (1947/2002b) highlight "rationalized mimesis" as a result of a process composed of three stages: the first one refers to the original mimesis, understood as a movement to make one equal to the environment in order to survive; the second stage appears in the organized manipulation of mimesis through magic; finally, the third stage would correspond to the repression of the first mimesis and its substitution for thought abstraction, the origin of enlightenment.

To Horkheimer and Adorno (1947/2002b), the mimetic rationality present in anti-Semitism reveals itself as a dynamic composed of repression and projection, in which the original mimesis, once repressed by civilization, is perceived by the anti-Semitic as inherently Jewish. This provokes, at the same time, repulsion and desire to eliminate the other, something expressed in these terms:

Those blinded by civilization have contact with their own tabooed mimetic traits only through certain gestures and forms of behavior they encounter in others, as isolated, shameful residues in their rationalized environment. What repels them as alien is all too familiar (Horkheimer \& Adorno, 1947/2002b: p. 149).

As such, what mobilizes the anti-Semitic structure is the so-called generalized idiosyncrasy, which, for Horkheimer and Adorno (1947/2002b), means the repulsion of the subject against nature not dominated by civilization. It reduces despised particularities to something natural that has to be subjugated-in this case, the Jews, reduced to the notion of "race". This structure had been provided by the Nazi ritual apparatus of uniforms and fascist symbols, an organized mimesis or mimesis of mimesis-that is, the rational organization of uncontrolled primary mimesis.

It is bound to this idea of a behavior with mimetic characteristics that in the sixth part of Elements Horkheimer and Adorno (1947/2002b) describe "false projection" as the opposite side of the primary mimesis. After all, it (the "false projection"):

...makes its surroundings resemble itself. If, for the former, the outward becomes the model to which the inward clings, so that the alien becomes the intimately known, the latter displaces the volatile inward into the outer world, branding the intimate friend as foe (p. 154).

As such, the repressed and impassible impulses of the prejudiced anti-Semite are directed towards their victim. Therefore, differing from the natural and adaptive projection, for the anti-Semite the object is determined by a rational norm of the world imposed by an outside that, once internalized and naturalized, goes on to be erroneously projected as one's own (that is, falsely defined by the subject as originated from their judgment). It is on these terms that, according to Horkheimer and Adorno (1947/2002b), false projection presents itself in the absence of reflection. Since the anti-Semite do not reflect on the object, he or she can no longer reflect on themselves, thus creating paranoia, which is taken as a rationalized interpretation of the world seeking to attend the needs of the paranoids themselves.

Based on these ideas, the last part of Elements goes on to refer to dominant social tendencies adhesion mechanisms in which the subject loses his or her capacity of experiencing, judging and reflecting, while those abilities are replaced by stereotypical mentality. In this sense, Horkheimer and Adorno (1947/2002b) define the ticket mentality as a set of ideological points arranged in blocks where, if the individual accepts any one of the points that form the ticket, he or she would adhere unreflectively to the other remaining points, thus occurring the process of elimination of the individual experience. In the case of anti-Semitism, any previous experience

\footnotetext{
${ }^{2}$ Horkheimer and Adorno (1947/2002a) comprehend enlightenment as totalitarian because it eliminates alterity. That is, it denies differences and all that resist to be portrayed by conceptual means. This issue, nominated by Adorno as the problem of the "non-identical", would be developed by the author in later works such as Negative Dialectics (Adorno, 1973) and Minima Moralia (Adorno, 1974).

${ }^{3}$ As Duarte (2002) and Alves Jr. (2003) recall, after inserting the notion of individual and, together with it, elements of Freudian thought in the last three theses on anti-Semitism, Horkheimer and Adorno (1947/2002b) end up pulling away from traditional Marxist view, presenting a theoretical approach whose reach overcomes references to purely economical factors as causes for intolerance and prejudice.
} 
regarding Jews would tend to be annulled and replaced by the disgust and desire to eliminate present on the fascist ticket.

Still, for Horkheimer and Adorno (1947/2002b) the problem is not only the ticket's content, but the ticket mentality itself since it is linked to intolerance in such a way that it is not presented as a choice, but as something essential for survival, guided by similar criteria used to choose a product for consumption. Taking into consideration that the way society is organized nowadays favors stereotypical thinking due to urgency for quick answers, then there's the mechanization and standardization of subjects, thus enforcing unreflective behavior.

Because of this, Horkheimer and Adorno (1947/2002b) have no qualms in stating something of great relevance and that is in direct reference to the analysis of bullying that we are proposing here: that psychological determinants that led to anti-Semitism (like the stereotypical "ticket mentality", for instance) did not fade away along with the Third Reich. On the contrary, they remain alive and well in contemporary times.

On the same note, another important statement of Horkheimer and Adorno (1947/2002b) about anti-Semitism is that, despite the fact that Elements focuses on intolerance towards Jews, the target of prejudice as a whole could not be reduced to one specific object. That's because ticket mentality could easily replace one target for another, revealing a social structure that does not tolerate difference and persecutes it. And so: It is not just the anti-Semitic ticket which is anti-Semitic, but the ticket mentality itself (Horkheimer \& Adorno, 1947/2002b).

In order to end this section, it is worth remembering that Horkheimer and Adorno (1947/2002b) understand prejudice as a result of the dialectical relationship that is established between the individual and society, a relationship that presents culture as its mediator. In this sense, as one of the fundamental theses present in Elements of Anti-Semitism, the authors also consider that the individual's disfigurement is inherent to how civilization was created, since persecuted groups historically vary according to how that same civilization is organized ${ }^{4}$.

\section{Final Considerations: Bullying, Intolerance and the Necessary Denaturalization of Prejudice}

The first aspect to be emphasized here is the approximation between bullying and prejudice, taking into account in this approach that bullying is surrounded by subjective conditions similar to those argued by Horkheimer and Adorno (1947/2002b) as facilitators of anti-Semitism in the context of World War II. For example, the fact that in the bullying dynamic the "target" tends to suffer aggression for being considered fragile and inferior. Alongside with unreflective behavior, this can indicate the aggressor's projection of fears, anguishes or characteristics that, while inappropriate, were repressed and became impossible of being recognized, which brings us back to the "uncanny" (Das Unheimliche) originally proposed by Freud (1919/1999). Considering this, it is not unreasonable to ask: can traces associated with bullying today be evidence or demonstrations of a much older phenomenon that has simply resurfaced under a different name?

Following this line of thought, another characteristic of bullying that, to our understanding, brings it closer to the Nazi-Fascist prejudice analysis proposed by Horkheimer and Adorno (1947/2002b) appears in the role of the "victim", which is usually interchangeable. This brings us back to the prevalence of the stereotypical ticket mentality that reduces the subjects to despised particularities and works as a legitimating element to persecutory action.

In a manner directly associated both to the notion of enlightenment (Aufklärung) and to stereotypical thinking, we also consider bullying, while being abstractly represented through concept, to promote a distance from reality, which provides an alienating attitude to the concept itself. As such, we believe that any restriction on aspects described in bullying's conceptual literature proves to be unreflective, as it does not create a direct link between subject and object, thus disconsidering other factors not made evident in conceptual terms, but that can be related to the phenomenon. These factors appear attached to contextual issues that, once neglected, allow only superficial analysis, whereas real advancement in knowledge happens upon reflection of the dialectic relation between abstraction and reality.

Taking that into account, it is worth mentioning the danger that, after being prematurely labeled as bullying,

\footnotetext{
${ }^{4}$ Late studies conducted throughout the 1950's, such as The Authoritarian Personality (Adorno et al., 1950), present several types of individuals that have in their subjective structure a tendency towards fascism. However, this is not about dividing individuals between prejudiced and unprejudiced. We can only argue that each subject can present an inclination to fascist tendencies on several levels, from inconspicuous to explicit (Alves Jr., 2003; Crochík, 2008). Based on these results, in another essay, named Prejudice and Character (Vorurteil und Character), Adorno and Horkheimer (1962/1997) established sociology's goal to be the study of the authoritarian character, of which the psychological aspects could turn an individual adept to authoritarian ideologies by the means of ticketmentality.
} 
several violent and cruel actions can be banalized and somehow accepted as inherent to the school environment. This perspective contributes to the reification of human being by presenting an indifferent view about him, a process which is also at the risk of reducing the subject to pre-established roles that, as we have seen, compose bullying (such as those of aggressor, victim and witness).

These conceptual naturalizations can be thought of as directly related to the practice of an adaptive education, heavily criticized by Adorno in works such as Education-What For? (Erziehung-wozu?) and Education for Autonomy (Erziehungzur Mündigkeit) (Adorno, 1971b, 1971d). So we ask: why not include here the notion of bullying? Therefore, it is necessary to pay attention to the predominance of adaptive education in the transmission of knowledge on this phenomenon, an education that disconsiders reflection and allows conditions for barbarism to emerge, the same barbarism that today is supposedly meant to be avoided by giving so much emphasis to the study of violence, intolerance and prejudice in school environments.

\section{References}

Adorno, T. W. (1971a). Erziehungnach Auschwitz. In Erziehungzur Mündigkeit. Vorträge und Gesprächemit Hellmut Becker 1959-1969 (pp. 92-109). Frankfurt: Suhrkamp.

Adorno, T. W. (1971b). Erziehung-wozu? In Erziehungzur Mündigkeit. Vorträge und Gesprächemit Hellmut Becker 1959-1969 (pp. 110-125). Frankfurt: Suhrkamp.

Adorno, T. W. (1971c). Erziehung zur Entbarbarisierung. In Erziehungzur Mündigkeit. Vorträge und Gesprächemit Hellmut Becker 1959-1969 (pp. 126-132). Frankfurt: Suhrkamp.

Adorno, T. W. (1971d). Erziehungzur Mündigkeit. In Erziehungzur Mündigkeit. Vorträge und Gesprächemit Hellmut Becker 1959-1969 (pp. 133-147). Frankfurt: Suhrkamp.

Adorno, T. W. (1973). Negative Dialectics. New York: Seabury Press.

Adorno, T. W. (1974). Minima Moralia: Reflections from Damaged Life. London: NLRB.

Adorno, T. W., \& Horkheimer, M. (1997). Vorurteil und Character. In Gesammelte Schriften, Band 9-2 (pp. 360-373). Frankfurt: Suhrkamp (Originally Published in 1962).

Adorno, T. W., Frenkel-Brunswik, E., Levinson, D. J., \& Sanford, R. N. (1950). The Authoritarian Personality. New York: Harper and Row.

Alves Jr., D. G. (2003). Depois de Auschwitz: A questão do anti-semitismo em Theodor W. Adorno. São Paulo: Annablume.

Antunes, D. C. (2008). Razão instrumental e preconceito: Reflexões sobre o bullying. Dissertation, São Carlos: Universidade Federal de São Carlos.

Antunes, D. C., \& Zuin, A. A. (2007). Uma versão contemporânea do preconceito: O bullying pela óptica da Teoria Crítica. Anais do XIV Encontro Nacional da Associação Brasileira de Psicologia Social, Rio de Janeiro, 31-3 Outubro/Novembro, 2007.

http://www.abrapso.org.br/siteprincipal/anexos/AnaisXIVENA/conteudo/pdf/trab completo 296.pdf

Bandeira, C. M. (2009). Bullying: Autoestima e diferenças de gênero. Dissertação, Porto Alegre: Universidade Federal do Rio Grande do Sul.

Crochík, J. L. (2008). O conceito de preconceito e a perspectiva da teoria crítica. In J. L. Crochík (Ed.), Perspectivas teóricas acerca do preconceito (pp. 69-101). São Paulo: Casa do Psicólogo.

Duarte, R. (2002). Adorno/Horkheimer e a dialética do esclarecimento. Rio de Janeiro: Jorge Zahar.

Fante, C. (2005). Fenômeno bullying—como prevenir a violência nas escolas e educar para a paz. Campinas: Verus Editora.

Freud, S. (1999). The “Uncanny”. In S. Freud (Ed.), The Standard Edition of the Complete Psychological Works of Sigmund Freud, Volume XVII (1917-1919): An Infantile Neurosis and Other Works (pp. 217-256). London: Vintage. (Originally published in 1919)

Honneth, A. (1988). Critical Theory. In A. Giddens, \& J. Turner (Eds.), Social Theory Today (pp. 347-382). Stanford, CA: Stanford University Press.

Horkheimer, M. (1976). Traditional and Critical Theory. In P. Connerton (Ed.), Critical Sociology: Selected Readings (pp. 206-224). Harmondsworth: Penguin. (Originally published in 1937)

Horkheimer, M., \& Adorno, T. W. (2002a). The Concept of Enlightenment. In Dialectic of Enlightenment: Philosophical Fragments (pp. 1-34). Stanford, CA: Stanford University Press. (Originally published in 1947)

Horkheimer, M., \& Adorno, T. W. (2002b). Elements of Anti-Semitism: Limits of Enlightenment. In Dialectic of Enlightenment: Philosophical Fragments (pp. 137-172). Stanford, CA: Stanford University Press. (Originally published in 1947)

Jay, M. (1996). The Dialectical Imagination: A History of the Frankfurt School and the Institute for Social Research 
1923-1950. Berkeley and Los Angeles, CA: University of California Press.

Kant, I. (1990). Critique of Pure Reason. Buffalo and New York: Prometheus Books. (Originally published in 1781)

Limber, S. P., \& Olweus, D. (2010). Bullying in School: Evaluation and Dissemination of the Olweus Bullying Prevention Program. American Journal of Orthopsychiatry, 80, 124-134. http://www.ncbi.nlm.nih.gov/pubmed/20397997 http://dx.doi.org/10.1111/j.1939-0025.2010.01015.x

Lopes-Neto, A. (2005). Bullying-Aggressive Behavior among Students. Journal of Pediatrics, 81, S164-S172. http://dx.doi.org/10.2223/JPED.1403

Matos, O. C. (1993). A escola de Frankfurt: Luzes e sombras do iluminismo. São Paulo: Moderna.

Nobre, M. (2008). Max Horkheimer: A teoria crítica entre o nazismo e o capitalismo tardio. In Curso livre de teoriacrítica (pp. 35-52). Campinas: Papirus Editora.

Olweus, D. (1993). Bullying at School: What We Know and What We Can Do (Understanding Children's Worlds). Oxford: Blackwell Publishing.

Olweus, D. (1997). Bully/Victim Problems in School: Facts and Intervention. European Journal of Psychology of Education, 12, 495-510. http://link.springer.com/article/10.1007\%2FBF03172807 http://dx.doi.org/10.1007/bf03172807

Olweus, D. (2003). A Profile of Bullying at School. Educational Leaderships, 60, 12-17. http://www.ascd.org/publications/educational-leadership/mar03/vol60/num06/A-Profile-of-Bullying-at-School.aspx

Olweus, D. (2013). School Bullying: Development and Some Important Challenges. Annual Review of Clinical Psychology, 9, 751-780. http://www.ncbi.nlm.nih.gov/pubmed/23297789 http://dx.doi.org/10.1146/annurev-clinpsy-050212-185516

Pereira, B. O. (2008). Para uma escola sem violência-Estudo e prevenção das práticas agressivas entre crianças. Cidade do Porto: Fundação Calouste Gulbenkian/Fundação para a Ciência e Tecnologia.

Rabaça, S. R. (2004). Variantes críticas: A dialética do esclarecimento e o legado da escola de Frankfurt. São Paulo: Annablume.

Ristum, M. (2010). Bullying escolar. In S. G. Assis, P. Constantino, \& J. Q. Avanci (Eds.), Impactos da violência na escola: Um diálogo com professors (pp. 95-119). Rio de Janeiro: Ministério da Educação/Editora FIOCRUZ.

Rush, F. (2004). Conceptual Foundations of Early Critical Theory. In F. Rush (Ed.), The Cambridge Companion to Critical Theory (pp. 6-39). Cambridge: Cambridge University Press. http://dx.doi.org/10.1017/CCOL0521816602.002

Slater, P. (1977). Origin and Significance of the Frankfurt School: A Marxist Perspective. London, Henley and Boston: Routledge \& Kegan Paul.

Solberg, M. E., Olweus, D., \& Endressen, I. M. (2007). Bullies and Victims at School: Are They the Same Pupils? British Journal of Educational Psychology, 77, 441-464. http://www.ncbi.nlm.nih.gov/pubmed/17504556 http://dx.doi.org/10.1348/000709906x105689

Tar, Z. (1977). The Frankfurt School: The Critical Theories of Max Horkheimer and Theodor W. Adorno. New York: John Wiley \& Sons.

Wiggershaus, R. (1994). The Frankfurt School: Its History, Theories, and Political Significance. Cambridge: MIT Press. 


\section{Submit or recommend next manuscript to SCIRP and we will provide best service for you:}

Accepting pre-submission inquiries through Email, Facebook, Linkedin, Twitter, etc A wide selection of journals (inclusive of 9 subjects, more than 200 journals)

Providing a 24-hour high-quality service

User-friendly online submission system

Fair and swift peer-review system

Efficient typesetting and proofreading procedure

Display of the result of downloads and visits, as well as the number of cited articles

Maximum dissemination of your research work

Submit your manuscript at: http://papersubmission.scirp.org/ 